\title{
Thermodynamic Principles of Dittmarite Precipitation
}

\author{
Asmare Atalay and Brodie Whitehead \\ Agricultural Research Station, Virginia State University, Petersburg, Virginia 23806, USA
}

\begin{abstract}
Dittmarite is a naturally occurring mineral which is also produced by municipal wastewater treatment processes. It contains ammonium:magnesium:phosphate in molar ratios of 1:1.25:1, respectively. Dittmarite $\left(\mathrm{MgNH}_{4} \mathrm{PO}_{4} \cdot \mathrm{H}_{2} \mathrm{O}\right)$ has a very stable crystalline structure, its solubility constant $\left(K_{s o}\right)$ is a product of the activity coefficient ( $\mathrm{\gamma}$ ) and the activity of the individual species that make up the compound. The conditional solubility product, $P_{S}=\mathrm{C}_{\mathrm{T}}, \mathrm{Mg} \mathrm{C}_{\mathrm{T}}, \mathrm{NH}_{4} \mathrm{C}_{\mathrm{T}}, \mathrm{PO}_{4}=K_{s o} / \alpha \mathrm{Mg} \alpha \mathrm{NH}_{4} \alpha \mathrm{PO}_{4} \mathrm{\gamma Mg} \mathrm{\gamma NH}_{4} 8 \mathrm{PO}_{4}$. A theoretical plot of - $\log$ Ps vs. $\mathrm{pH}$ gives a $\mathrm{pH}$ of 10.7 for maximum dittmarite precipitation, albeit precipitation may begin at lower $\mathrm{pH}$ values. The $\mathrm{p} K_{s o}$ for dittmarite at $25{ }^{\circ} \mathrm{C}$ is determined to be 13.359 from the final equilibrium $\mathrm{pH}$ values taking all relevant magnesium, phosphate and ammonium species into account. The geochemical speciation model, MINTEQA2 was used to verify the optimum conditions for the precipitation of dittmarite. Such theoretical predictions allow the control of phosphorus and nitrogen discharges from animal and municipal wastewaters and serve as key factors in preventing surface water eutrophication and groundwater pollution.
\end{abstract}

Key words: Dittmarite, precipitation, thermodynamics, MINTEQA2, wastewater.

\section{Introduction}

Use of phosphorus and nitrogen enriched feeds in CAFO (Confined Animal Feeding Operations), land application of animal manure and chemical fertilizer on agricultural land, and municipal as well as industrial wastewaters, all contribute a great deal to the eutrophication of surface waters. Application of manure slurries to crop land beyond allowable limits results in high levels of phosphorus and nitrogen in runoff that negatively impact aquatic animals. Municipal wastewater treatment plants are setup to remove these nutrients from domestic and industrial wastewater through a network of treatment processes. Thus, controlling the discharge of phosphorus and nitrogen in wastewater is a key factor in preventing eutrophication. Authors' previous research [1] has developed and enhanced a chemical precipitation method that removes over $90 \%$ of phosphorus and nearly $20 \%$ of nitrogen from both synthetic and municipal wastewaters as dittmarite. While various

Corresponding author: Asmare Atalay, Ph.D., research professor, main research fields: soil chemistry and environmental science. VSU-ARS Publication No. 533. phosphate forms are present in nature, the most common is calcium phosphate which is stable at very high $\mathrm{pH}$. Among other phosphates, one with practical relevance is dittmarite $\left(\mathrm{MgNH}_{4} \mathrm{PO}_{4}\right)$. Dittmarite appears naturally in bat guano and as a nuisance precipitate in conduits at municipal wastewater treatment plants. Most recently, dittmarite and its hexahydrate form, struvite, have found relevance as value-added products in agriculture. Dittmarite has been postulated to form as intermediate reaction product before it transforms into the more stable hexahydrate, struvite [2]. Many interesting data are available concerning factors involved in precipitation of dittmarite/struvite in phosphorus recovery processes in wastewater treatment systems as well as their occurrence in geologic deposits. Precipitation of dittmarite/struvite has been studied with regard to solution composition and $\mathrm{pH}$, and attention has been given to the kinetics and mechanism of dittmarite/struvite precipitation in the condition of constant supersaturation [3]; with special consideration to the possible difference in the solubility and dissolution kinetics of different dittmarite/struvite morphologies [4]. 
Precipitation of $\mathrm{P}$ in the form calcium phosphate is not a new idea, it has been known since 1939 [5]. In fact, such a precipitate had been considered a nuisance by wastewater engineers since it clogged transfer lines preventing normal flow of wastewater [6]. However, precipitation of $\mathrm{P}$ as dittmarite, a potentially value added product, is not widely known. Dittmarite is a monohydrated magnesium ammonium phosphate crystal which is drier and finer in particle size than the amorphous phosphate, and easily managed for transport and land application purposes. Understanding dittmarite formation in a solution that contains other organic and inorganic constituents is a challenge. However the process can be simplified by initially dissolving the inorganic and organic species with mineral acid. Authors' preliminary work has indicated that use of a chelating substance was beneficial since it trapped excess positive ions and brought them into solution. Additional magnesium source was needed to overwhelm the system and occupy all active sites. In the process freed magnesium was able to combine with free ammonium and phosphate ions to form dittmarite. The choice of which form of magnesium to use usually depends on the characteristic of the waste to be treated. Authors used a magnesium source in the trial studies that enhanced dittmarite formation. However, Miles and Ellis [7] encountered difficulty in precipitating phosphate-bearing minerals from wastewater when they used a 50\% magnesium hydroxide slurry and a phosphate fertilizer to reduce ammonia content. Because of the low solubility of magnesium oxide, the reaction time was longer and residual magnesium oxide existed after the reaction. However, magnesium chloride could be a good precipitant for dittmarite formation since the $\mathrm{pH}$ would be better controlled. It might be slightly acidic compared to the other forms of magnesium, in which case precautions might be needed to control the $\mathrm{pH}$. Authors' preliminary laboratory studies have indicated that in order to obtain optimum results for dittmarite precipitation, the magnesium chloride or magnesium hydroxide molar ratio to phosphate ratio should be specific. Kofina and Koutsoukos [8] reported that total suspended solids above $1,000 \mathrm{mg} / \mathrm{L}$ interfered with the phosphate precipitation process. One way to overcome it, based on our preliminary studies, would be to lower the $\mathrm{pH}$ and allow the acidification process to dissolve the solids.

\section{Materials and Methods}

\subsection{Equilibrium Speciation Modeling}

The geochemical speciation model, MINTEQA2 [9] allows full speciation of the dittmarite system to compute the concentration of each species: $\mathrm{H}_{2} \mathrm{PO}_{4}{ }^{-}$, $\mathrm{H}_{3} \mathrm{PO}_{4}, \mathrm{OH}^{-}, \mathrm{NH}_{3}(\mathrm{aq}), \mathrm{MgOH}^{+}, \mathrm{MgOH}^{-}, \mathrm{MgPO}_{4}^{-}$, $\mathrm{MgH}_{2} \mathrm{PO}_{4}{ }^{+}, \mathrm{MgHPO}_{4}(\mathrm{aq}), \mathrm{HPO}_{4}{ }^{2-}, \mathrm{Mg}^{2+}, \mathrm{PO}_{4}{ }^{3-}$ and $\mathrm{NH}_{4}{ }^{+}$. The equilibrium equations given in Table 1 describe the possible reactions and species that form during dittmarite formation.

Table 1 Equilibrium constants for the various reactions and potential species used in the MINTEQA2 speciation model to determine dittmarite precipitation [10].

\begin{tabular}{lll}
\hline Equilibrium & $\log K$ at $37^{\circ} \mathrm{C}$ & $\log K$ at $25^{\circ} \mathrm{C}$ \\
\hline $\mathrm{H}_{2} \mathrm{PO}_{4}{ }^{-}+\mathrm{H}^{+} \rightleftharpoons \mathrm{H}_{3} \mathrm{PO}_{4}$ & 2.21 & 2.148 \\
$\mathrm{HPO}_{4}{ }^{2-}+\mathrm{H}^{+} \rightleftharpoons \mathrm{H}_{2} \mathrm{PO}_{4}^{-}$ & 7.18 & 7.198 \\
$\mathrm{PO}_{4}{ }^{3-}+\mathrm{H}^{+} \rightleftharpoons \mathrm{HPO}_{4}{ }^{2-}$ & 12.18 & 12.375 \\
$\mathrm{HPO}_{4}{ }^{2-}+\mathrm{Na}^{+} \rightleftharpoons \mathrm{NaHPO}_{4}^{-}$ & 0.85 & 0.85 \\
$\mathrm{H}_{2} \mathrm{PO}_{4}{ }^{-}+\mathrm{Mg}^{2+} \rightleftharpoons \mathrm{MgH}_{2} \mathrm{PO}_{4}{ }^{+}$ & 1.207 & 1.207 \\
$\mathrm{HPO}_{4}{ }^{2-}+\mathrm{Mg}^{2+} \rightleftharpoons \mathrm{MgHPO}_{4}$ & 2.815 & 2.428 \\
$\mathrm{PO}_{4}{ }^{3-}+\mathrm{Mg}^{2+} \rightleftharpoons \mathrm{MgPO}_{4}{ }^{-}$ & 4.92 & 4.92 \\
$\mathrm{SO}_{4}{ }^{2-}+\mathrm{H}^{+} \rightleftharpoons \mathrm{HSO}_{4}^{-}$ & 2.03 & 1.99 \\
$\mathrm{SO}_{4}{ }^{2-}+\mathrm{Mg}^{2+} \rightleftharpoons \mathrm{MgSO}_{4}$ & 1.97 & 2.23 \\
$\mathrm{NH}_{4}{ }^{+} \rightleftharpoons \mathrm{NH}_{3}(\mathrm{aq})+\mathrm{H}^{+}$ & 9.25 & 9.24 \\
$\mathrm{H}_{2} \mathrm{O} \rightleftharpoons \mathrm{H}^{+}+\mathrm{OH}^{-}$ & -13.62 & -13.997 \\
\hline
\end{tabular}


The applicable mass balance, acid-base and complex formation equilibria equations for dittmarite (struvite) chemistry are given by Buchanan [6]. MINTEQA2 modeling was used in conjunction with laboratory experiments to predict the potential for dittmarite precipitation as a function of $\mathrm{pH}$ and magnesium, ammonium and phosphate molar ratio. Each model prediction was run at a temperature of $25{ }^{\circ} \mathrm{C}$ and negligible ionic strength. If the ionic strength is fixed, it becomes independent of the solution chemistry [9]. This means, there could be inert ions present in large enough concentrations such that their impact on ionic strength might be important. To satisfy this curiosity, a separate run was done that included all other major ions in the solution. However, no major difference was seen in the results as compared to the limited input. The runs were performed over a series of $\mathrm{pH}$ values to determine how the concentrations of each constituent change with $\mathrm{pH}$. The pilot-scale study conducted for use in the MINTEQA2 speciation model is described in a previous study [1].

\subsection{Theoretical Development}

Dittmarite and struvite have very low solubility in water (approximately $160 \mathrm{mg} / \mathrm{L}$ at $\mathrm{pH} 7$ and $25{ }^{\circ} \mathrm{C}$ ) with a solubility product (Ksp) between $10^{-10}$ and $10^{-13.3}[4,6,11-13]$. For dittmarite, $\mathrm{MgNH}_{4} \mathrm{PO}_{4} \cdot \mathrm{H}_{2} \mathrm{O}$, the equilibrium solubility constant can be expressed as follows [14]:

$$
\begin{gathered}
K s o=\left\{\mathrm{Mg}^{+2}\right\}\left\{\mathrm{NH}^{4+}\right\}\left\{\mathrm{PO}_{4}{ }^{3-}\right\} \\
=8 \mathrm{Mg}^{+2}\left[\mathrm{Mg}^{+2}\right] \mathrm{\gamma NH}_{4}^{+}\left[\mathrm{NH}_{4}{ }^{+}\right] \mathrm{\gamma PO}_{4}{ }_{4}{ }^{3-}\left[\mathrm{PO}_{4}{ }^{3-}\right] \\
=\mathrm{\gamma Mg}^{2+} \mathrm{C}_{\mathrm{T}}, \mathrm{Mg} \alpha \mathrm{Mg}^{2+} \cdot \mathrm{\gamma NH}_{4}{ }_{4}^{+} \mathrm{C}_{\mathrm{T}}, \mathrm{NH}_{4}{ }^{+} \alpha \mathrm{NH}_{4}{ }^{+} \cdot \\
\mathrm{\gamma PO}_{4}{ }^{3-} \mathrm{C}_{\mathrm{T}}, \mathrm{PO}_{4}{ }^{3-} \alpha \mathrm{PO}_{4}{ }^{3-}
\end{gathered}
$$

The conditional solubility product, $P_{S}$, becomes:

$$
P_{S}=\mathrm{C}_{\mathrm{T}}, \mathrm{Mg} \mathrm{C}_{\mathrm{T}}, \mathrm{NH}_{4} \mathrm{C}_{\mathrm{T}} \text {, }
$$

$\mathrm{PO}_{4}=K_{S O} / \alpha \mathrm{Mg} \alpha \mathrm{NH}_{4} \alpha \mathrm{PO}_{4}>\mathrm{Mg} \gamma \mathrm{NH}_{4}{ }_{8} \mathrm{PO}_{4}$

Then, $P S$ is a function of $\mathrm{pH}$ and their relationship can be plotted as shown in Fig. 1. This minimum value will occur when the product $\left(\mathrm{\gamma Mg}^{2+}\right) \times\left(\mathrm{\gamma NH}_{4}{ }^{+}\right)$ $\times\left({ } \mathrm{PO}_{4}{ }^{3-}\right)$ is a maximum. The conditional solubility product of magnesium ammonium phosphate, dittmarite, illustrates a situation where more than one of the dissolving species is affected by solution $\mathrm{pH}$. These species are the ammonium ion $\left(\mathrm{HN}_{4}{ }^{+}\right)$and the phosphate ion $\left(\mathrm{PO}_{4}{ }^{3-}\right)$. Because an increase in $\mathrm{pH}$ will decrease the ammonium ion concentration and increase the phosphate ion concentration, it follows that there should be a $\mathrm{pH}$ value where the solubility of $\mathrm{MgNH}_{4} \mathrm{PO}_{4}$ (s) is a minimum (Fig. 1).

The minimum value for $P s$ occurs when the product $\alpha \mathrm{Mg} \alpha \mathrm{NH}_{4} \alpha \mathrm{PO}_{4}$ is a maximum. From the above figure, the minimum solubility $(P S)$ occurs when $\mathrm{pH}=10.7$, which indicates the maximum precipitation of ammonium as dittmarite [15]. Beyond $\mathrm{pH}=10.7$, various species of calcium phosphate such as hydroxylapatite and amorphous phosphate forms of aluminum and iron phosphates also precipitate.

\subsection{Dittmarite Precipitation and X-Ray Diffraction}

Dittmarite samples from the pilot study [1] were dried in oven at $105{ }^{\circ} \mathrm{C}$ and prepared for further analysis. The resulting white crystalline powder (Fig. 2) was analyzed for phase identification using a Rigaku micro XRD (X-Ray Diffraction) system using a $\mathrm{Cu} \mathrm{K} \alpha$ rotating anode, operating at $40 \mathrm{kV} / 20 \mathrm{~mA}$ and an imaging plate for detection. A small amount of

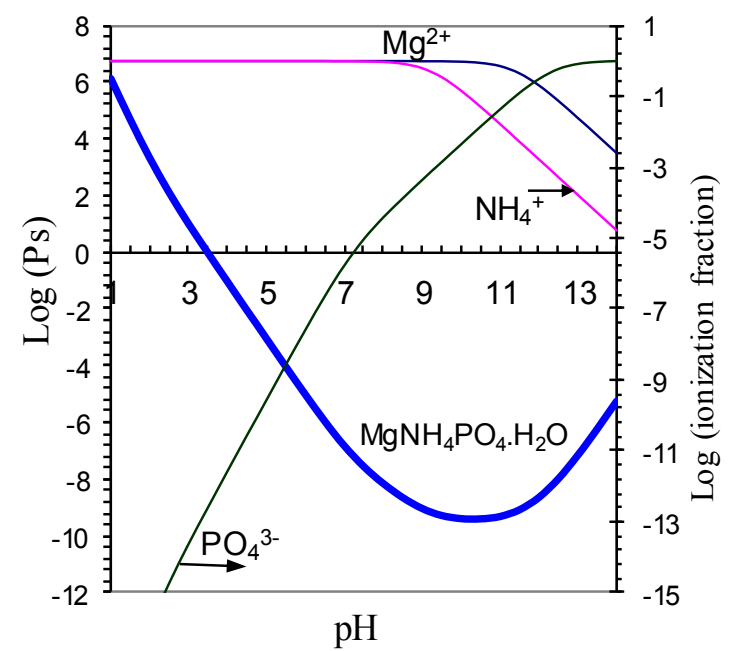

Fig. 1 Theoretical relationship between the conditional solubility product, $P_{S}$ and $\mathbf{p H}$ indicating maximum precipitation of dittmarite at $\mathrm{pH} \mathbf{1 0 . 7}$ 
the sample was placed inside a $0.1 \mathrm{~mm}$ S-glass capillary, positioned at the center of four-circle goniometer and rotated $360^{\circ}$ continuously in a plane parallel to the beam. The sample was irradiated for 15 minutes, and system software was used to integrate each image to create a $2 \theta$ versus intensity plot. The pattern was checked for matches in our ICDD (International Center for Diffraction Data) database of diffraction patterns. Then a small amount of the powder was placed on a carbon adhesive tab to verify the elemental composition using EDS (Energy-Dispersive X-Ray Spectrometry). The sample pattern matched the ICDD reference for dittmarite with minor mixtures of newberyite and mascagnite.

Dittmarite was obtained from both wastewater and via synthesis using laboratory chemicals. It can be characterized by its physical and chemical properties. XRD of the material synthesized in the laboratory was confirmed to be dittmarite (see Fig. 3). The presence of dittmarite is indicated by the location of intensity peaks. Vertical lines on the graph represent where the dittmarite peaks should occur. Some of the more definite non-dittmarite peaks show the presence of other minerals, newberyite and mascagnite. This indicates that $\mathrm{P}$ precipitates other than dittmarite are forming in the reaction process. The formed precipitate is enhanced with $\mathrm{P}$ not only from dittmarite but also from newberyite, mascagnite and other unidentified P-bearing minerals shown in the XRD diagram.

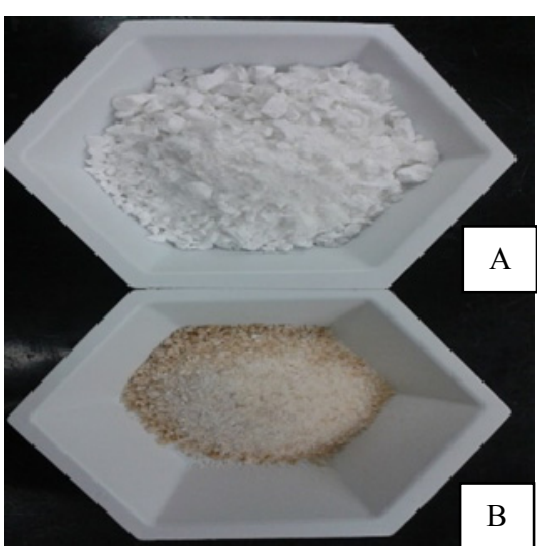

Fig. 2 Dittmarite precipitated from (A) synthetic chemicals and (B) wastewater.

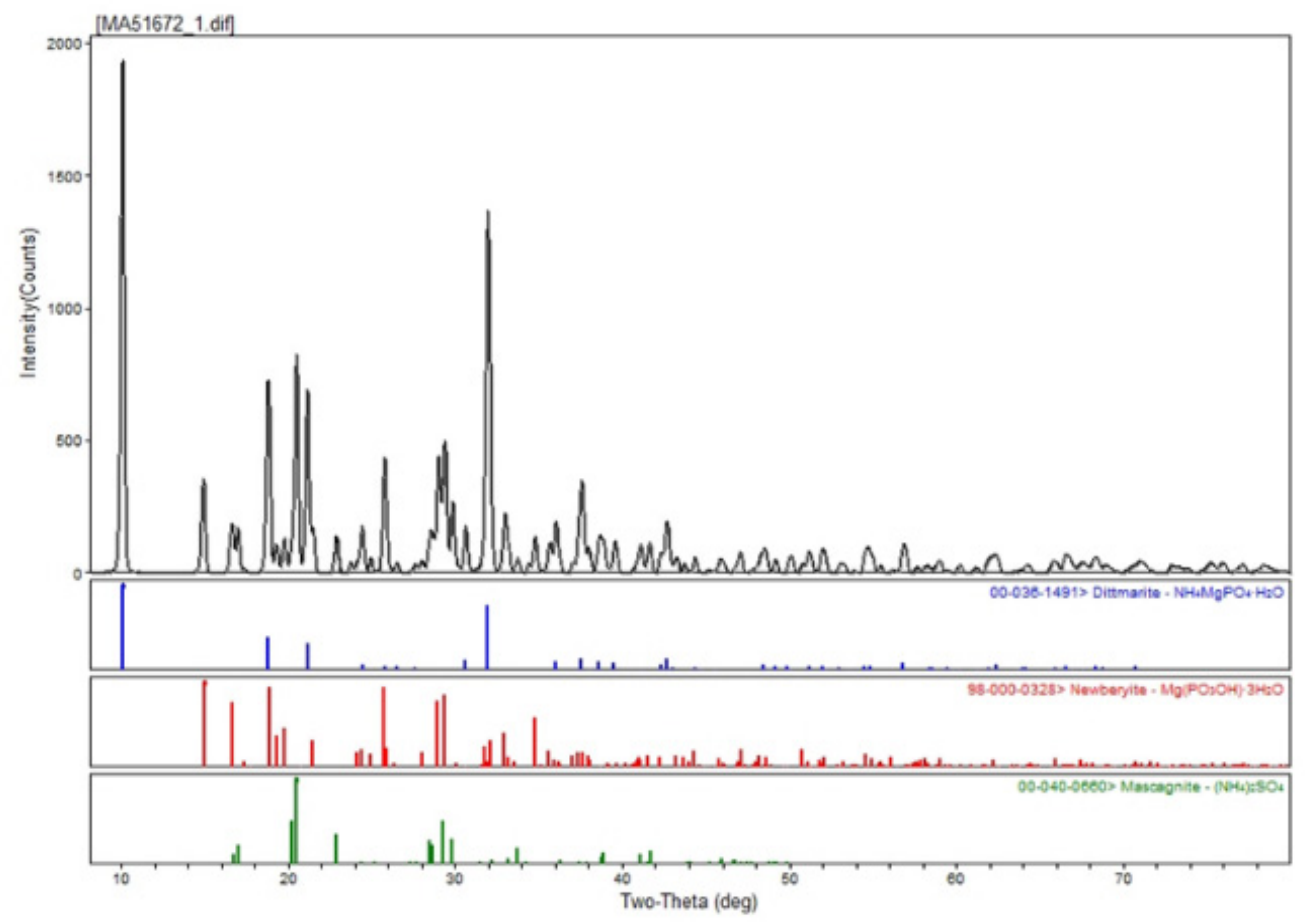

Fig. 3 XRD results of dittmarite showing the specific peak characteristics. 


\section{Results and Discussion}

Since magnesium is considered to be the main ingredient needed for the precipitation of phosphorus and nitrogen from wastewater, the following are basic reactions that occur when dittmarite is precipitated in the presence of various sources of magnesium, ammonium and phosphate:

$$
\begin{array}{r}
\left(\mathrm{NH}_{4}\right)_{3} \mathrm{PO}_{4}+\mathrm{MgCl}_{2}+\mathrm{H}_{2} \mathrm{O} \Leftrightarrow \mathrm{MgNH}_{4} \mathrm{PO}_{4} \cdot \mathrm{H}_{2} \mathrm{O}(1) \\
\left(\mathrm{NH}_{4}\right)_{2} \mathrm{HPO}_{4} \mathrm{MgO}+\mathrm{H}_{2} \mathrm{O} \Leftrightarrow \mathrm{MgNH}_{4} \mathrm{PO}_{4} \cdot \mathrm{H}_{2} \mathrm{O}(2) \\
\left(\mathrm{NH}_{4}\right)_{3} \mathrm{PO}_{4}+\mathrm{MgCO} 3+\mathrm{H}_{2} \mathrm{O} \Leftrightarrow \mathrm{MgNH}_{4} \mathrm{PO}_{4} \cdot \mathrm{H}_{2} \mathrm{O}(3) \\
\left(\mathrm{NH}_{4}\right)_{3} \mathrm{PO}_{4}+\mathrm{Mg}(\mathrm{OH})_{2}+\mathrm{H}_{2} \mathrm{O} \Leftrightarrow \mathrm{MgNH}_{4} \mathrm{PO}_{4} \cdot \mathrm{H}_{2} \mathrm{O}(4) \\
\left(\mathrm{NH}_{4}\right)_{3} \mathrm{PO}_{4}+\mathrm{MgSO}_{4}+\mathrm{H}_{2} \mathrm{O} \Leftrightarrow \mathrm{MgNH}_{4} \mathrm{PO}_{4} \cdot \mathrm{H}_{2} \mathrm{O}(5) \\
\text { Other forms of P-bearing minerals have been }
\end{array}
$$
known to cause major problems in wastewater. A historical problem in wastewater treatment plants is the precipitation of $\mathrm{P}$ as calcium phosphate in the presence of high levels of dissolved calcium followed by the formation of dittmarite as described by the following reactions:

$$
\begin{gathered}
3 \mathrm{Ca}^{2+}+2 \mathrm{PO}_{4}{ }^{3-} \rightarrow \mathrm{Ca}_{3}\left(\mathrm{PO}_{4}\right)_{2} \\
\mathrm{CaPO}_{4}+\mathrm{Mg}^{+2}+\mathrm{NH}_{4}^{+}+\mathrm{H}_{2} \mathrm{O} \rightarrow \mathrm{MgNH}_{4} \mathrm{PO}_{4} \cdot \mathrm{H}_{2} \mathrm{O} \text { (7) }
\end{gathered}
$$

However, such problems could be avoided by slowly adding a strong mineral acid solution to the wastewater. This would partially digest the organic matter and dissolve minerals to release all bound metals into solution. Alternatively one can use EDTA, which has the advantage of binding calcium ions, may be added to release the phosphate ions into solution as described by the Eq. (8):

$$
\mathrm{Ca}_{3}\left(\mathrm{PO}_{4}\right)_{2}+\mathrm{EDTA} \rightarrow \mathrm{EDTA}-\mathrm{Ca}+\mathrm{PO}_{4}{ }^{3-}
$$$$
\text { (note the free phosphate in solution) }
$$

The free phosphate ion would now be available to combine with ammonium and magnesium ions in solution to form dittmarite. In the wastewater treatment scenario, once the wastewater reaches the treatment plant, the $\mathrm{pH}$ would be raised and a high dose of magnesium added to force the reaction towards dittmarite formation. It would be prudent to add more magnesium to enhance the precipitation of dittmarite. The stability constant for EDTA-Mg complex is $10^{+8.7}$ [16-18] which means magnesium will be bound and unable to precipitate $\mathrm{P}$ as dittmarite. Zhang, et al. have noticed that when the magnesium concentration was increased by more than twice that of EDTA, a sharp reduction in $\mathrm{P}$ was observed due to the formation of P-bearing minerals [2]. It is also interesting to note that in the process of dittmarite formation, calcium is usually considered an impurity because the calcium ion can block the active site on the crystal lattice. Increase in calcium concentration is expected to inhibit dittmarite growth and lead to the formation of an amorphous substance rather than the desired crystalline dittmarite. The same principle would apply during the process of dittmarite precipitation from animal and municipal wastewaters.

Since authors' overall goal is to recover $\mathrm{P}$ from wastewater, the result we obtained in the preliminary trial [1] is a favorable one. The following chemical analyses provide values that are pertinent for evaluating dittmarite as a fertilizer source: Magnesium, $15.65 \%$ as $\mathrm{Mg}$ or $25.95 \%$ as $\mathrm{MgO}$; Phosphorus, $19.94 \%$ $\mathrm{P}$ or $45.69 \% \mathrm{P}_{2} \mathrm{O}_{5}$; Nitrogen $9.02 \% \mathrm{~N}$ or $16.76 \%$ $\left(\mathrm{NH}_{4}\right)_{2} \mathrm{O}$. These values are about twice the amount found in ammonium magnesium phosphate hexahydrate; and they provide over four times the phosphorus and about two times the nitrogen in a regular 10-10-10 fertilizer. Therefore precipitating $\mathrm{P}$ as dittmarite has more environmental and agricultural advantages over other forms of P-bearing minerals. In the laboratory study, dittmarite was recovered by gravity settling followed by centrifugation. The result was a crystalline powder similar to very fine sand (Fig. 2a). We believe the texture can be enhanced by adding fine sand of similar particle size, a process called nucleation that can be applied at the final recovery stage of wastewater treatment. This will permit ease of handling and transportation of dittmarite.

\section{Conclusion}

Dittmarite is the monohydrated version of struvite, which is considered a nuisance in wastewater 
treatment processes. Dittmarite is a naturally occurring mineral which is also found in bat guano. The use of MINTEQA2 speciation model along with theoretical chemical equilibria was able to predict the optimum $\mathrm{pH}$ under which dittmarite is precipitated from wastewater. X-Ray diffraction and chemical analysis have revealed that dittmarite in its purest form is a white crystalline mineral with very low solubility in water (about $160 \mathrm{mg} / \mathrm{L}$ ) at $25{ }^{\circ} \mathrm{C}$. The chemical composition of dittmarite reveals that it could be commercialized as an alternative fertilizer supplement.

\section{References}

[1] Atalay, A., Whitehead, B. L., Oyewole, O., and Brown, Z. 2017. "Removal of Nitrogen and Phosphorus from animal and Municipal Wastewaters as Dittmarite." J. Environ. Sci. and Engineering B 6: 295-300.

[2] Zhang, T., Bowers, K. E., Harrison, J. H., and Chen, S. 2010. "Releasing Phosphorus from Calcium for Struvite Fertilizer production from Anaerobically Digested Dairy Effluent." Water Environment Research 82 (1): 34-42.

[3] Sarkar, A. K. 1991. "Hydration/Dehydration Characteristics of Struvite and Dittmarite Pertaining to Magnesium Ammonium Phosphate Cement System." J. Material Sci. 26: 2514-8.

[4] Bhuiyan, M. I. H., Marvinic, D. S., and Beckie, R. D. 2007. "A Solubility and Thermodynamic Study of Struvite." Environ. Tech. 28 (9): 1015-26.

[5] Rawn, A. M., Banta, A. P., and Pomeroy, R. 1939. "Multiple Stage Sewage Digestion." Trans. Am. Soc. Civil Eng. 105: 93-132.

[6] Buchanan, J. R., Mote, C. R., and Robinson, R. B. 1994. "Thermodynamics of Dtruvite Formation." Transactions of the ASAE 37 (2): 617-21.

[7] Miles, A., and Ellis, T. G. 1999. "Struvite Precipitation Potential for Nutrient Recovery from Anaerobically
Treated Waste." In Proceedings of the ASCE 1999 National Conference on Environmental Engineering, June 7-10, 1999. Chicago, Illinois, 161-6.

[8] Kofina, A. N., and koutsoukos, P. G. 2005. "Spontaneous Precipitation of Struvite from Synthetic Wastewater Solution." Crystal Grouth and Design 5: 489-96.

[9] USEPA. 1991. MINTEQA@, U.S. Environmental Protection Agency. www.epa.gov/ceampubl/mmedia/minteq 301/11/2010.

[10] Smith, R. M., and Martell, A. E. 1989. Critical Stability Constants. Vol. 6, Plenum Press.

[11] Burns, J. R., and Finlayson, B. 1982. "Solubility Product of Magnesium Ammonium Phosphate Hexahydrate at Various Temperatures." J. Urology 128: 426-8.

[12] Taylor, A. W., Frazier, A. W., and Gurney, E. L. 1963. "Solubility Products of Magnesium Ammonium and Magnesium Potassium Phosphates." Transactions Faraday Society 59: 1580-4.

[13] Web, K. M., and Ho, G. E. 1992. "Struvite $\left(\mathrm{MgNH}_{4} \mathrm{PO}_{4} \cdot 6 \mathrm{H}_{2} \mathrm{O}\right)$ Solubility and Its Application to Piggery Effluent Problem." Water Science Technology 26 (9-11): 2229- 32.

[14] Stumm, W., and Morgan, J. J. 1981. Aquatic Chemistry: An Introduction Emphasizing Chemical Equilibria in natural Waters. New York: John Wiley \& Sons.

[15] Babic-Ivancic, V., Kontrec, J., Kralj, D., and Brecevic, L. 2002. "Precipitation Diagrams of Struvite and Dissolution Kinetics of Different Struvite Morphologies." Croatica Chemica Acta 75 (1): 89-106.

[16] Sawyer, C., McCarty, P., and Parkin, G. 1994. Chemistry for Environmental Engineering (4th ed.). New York: McGraw Hill.

[17] Snoyink, V. L., and Jenkins, D. 1980. Water Chemistry. New York: John Wiley \& Sons.

[18] Benefield, L. D., Judkins, J. F., and Weand, B. L. 1982. Process Chemistry for Water and Watewater Treatment. Englewood Cliff, NJ: Prentice-Hall Inc..

[19] LeCorree, K. S., Valsami-Jones, E., Hobbs, P., and Parson, S. A. 2005. "Impact of Calcium on Struvite Crystal Size, Shape and Purity." J. Cryst. Gropwth 283: 514-22. 